\title{
Incorporating Active Learning and Student Inquiry into an Introductory Merchandising Class
}

\author{
Hyun-Hwa Lee \\ Inha University, Republic of Korea \\ E-mail: hyunhwa@inha.ac.kr \\ Jean D. Hines \\ Bowling Green State University, Ohio, U.S.A \\ E-mail: hines@bgsu.edu
}

Received: January 3, 2012 Accepted: January 16, $2012 \quad$ Published: March 1, 2012

doi: $10.5539 /$ hes.v2n1p55

URL: http://dx.doi.org/10.5539/hes.v2n1p55

\begin{abstract}
Many educators believe that student learning is enhanced when they are actively involved in classroom activities that require student inquiry. The purpose of this paper is to report on three student inquiry projects that were incorporated into a merchandising class with the focus on making students responsible for their learning, rather than the teacher. The students' evaluations of the projects were very positive. In written evaluations of the class, many expressed liking the projects and described them as a very useful way to learn and understand the class topics and contents. These responses suggest that the active learning and student inquiry strategy was helpful to the students in understanding the content of the course. It is recommended that educators actively involve students in the learning process by developing projects that require student inquiry. Additional research to analyze the benefits and limitations of active learning and inquiry and to examine how institutions can support faculty to implement active learning should be conducted.
\end{abstract}

Keywords: Active learning, Student inquiry, Merchandising class

\section{Introduction}

Educators have recognized the importance of student-centered learning in the college classroom. They have found that students learn best when they are actively involved in the classroom activities. The importance of student inquiry and active learning has received much attention in higher education (Bonwell \& Eison, 1991; Luckie et al., 2004; Myers \& Jones, 1993; Umbach et al., 2005; van Zee, 2000; Yoder \& Hochevar, 2005). When teachers apply an active learning strategy, students perform tasks that require them to think (Bonwell \& Eison, 1991; Wilke, 2003; Yoder \& Hochevar, 2005). Mattsons (2005) describes active learning as learning by doing, which not only develops students' thinking abilities, but also enables them to retain the subject matter (Myers \& Jones, 1993).

One objective of active learning and student inquiry is to shift the focus (and the responsibility) of learning from the teacher to the student (Luckie et al., 2004; Scholes, 2002). Another objective is to inspire learning and creative thinking (Kumar, 2003). In addition, active learning increases both student enjoyment and learning (Fox-Cardamone \& Rue, 2003). Fox-Cardamone and Rue (2003) describe the importance of active learning in helping students connect new knowledge to previously learned information in order to increase understanding and retention. Active learning is expected to construct meaningful learning, improve interest in learning, increase knowledge and retention, promote self- regulated and self-reliant learners and increase students' self-efficacy (Wilke, 2003).

Students' inquiry allows them to ask and answer their own questions so that they can better understand the class content. In doing so, students assume responsibility for their own learning and knowledge by doing more work (Luckie et al., 2004). Student inquiry is important because it promotes deeper understanding of the materials and helps students to formulate and ask probing questions (Eyler, 2000; Luckie et al., 2004). Student inquiry focuses on generating questions, investigating, observing, and analyzing problems (Luckie et al., 2004; van Zee, 2000) It involves group discussion, outlines, small group activities, problem solving, student-instructor feedback, and role playing (Kane, 2004; Morgan, 2003; Yoder \& Hochevar, 2005). 
Active learning and student inquiry based learning can be used across disciplines (Kane, 2004; Luckie et al., 2004; Morgan, 2003; Wilke, 2003; Wood, 2005; Yoder \& Hochevar, 2005; van Zee, 2000). Wood (2005) constructed a student-centered course outline to encourage presentations, group work, and research. Yoder and Hochevar (2005) use small-group and class discussions, simulations, videos, demonstrations and exercises in a women's undergraduate psychology class. Morgan (2003) incorporated active learning in his international politics course by using role-playing, simulations and group problem solving.

In active learning and student inquiry, instructors are the ones who organize the activities to encourage the students' learning based on doing and thinking (Kane, 2004; Morgan, 2003; Umbach \& Wawrzynski, 2005; Yoder \& Hochevar, 2005). As a mediator, the teacher gets between the method and the students. This is crucial to stimulate active learning and students' inquiry (Umbach \& Wawrzynski, 2005). Teachers need to have clear ideas on how to implement a variety of learning techniques in class (Yoder \& Hochevar, 2005). Students' inquiry has been emphasized at the university at which the authors of this study teach to encourage a learner-centered classroom environment and undergraduate research. When students encountered the university curriculum and especially their first major course, the training process and the formation of their expectations for the major were crucial for their professional future. Active learning and students' inquiry are a necessary step in that direction. As instructors of an introductory class of merchandising, we applied the active learning strategy by incorporating students' inquiry throughout the semester. With the purpose of the shifting the responsibility of the learning from the teacher to the students (Luckie et al., 2004; Scholes, 2002), we focused class projects on active learning and student inquiry to make students responsible for their learning rather than the teacher. The purpose of this paper is to share our practices and experiences with incorporating three active learning and students' inquiry projects into an introductory merchandising class.

\section{The Purpose of the Introductory Merchandising Class}

The introductory merchandising course provides general information about the textiles and apparel industry and its academic and career possibilities. The textile and apparel industry is highly dynamic and rapidly-changing. It is important for instructors to stay abreast of current issues and research. However, active learning requires both the instructors' and students' participation. We believe that conducting an in-depth inquiry requires students to engage in critical thinking tasks such as analysis, synthesis, and evaluation. The students in the class are therefore required to complete three individual and team projects during the semester.

\section{Research Method}

The present study applies several active learning and student inquiry strategy into the introductory merchandising class. The purpose of the projects and process related to active learning and students' inquiry are given as well as the opportunities provided to the students to practice this learning strategy. The next section provides the information about different types of student inquiry projects integrated into the class in detail.

\section{Application of Active Learning and Student Inquiry into an Introductory Merchandising Class}

The first assignment is to review important textile and apparel trade publications (e.g., WWD, DNR, Textile world, Stores, Apparel, Earnshaw's etc.). The purpose of this assignment is to familiarize students with various professional industry publications, which will be useful resources for them as professionals in the apparel and textile industry. Throughout the semester, students are assigned a specific print publication to review based on the topic being discussed in class. For example, when the topic is types of retail formats, students review Stores magazine. Students are required to review the print version of the publication, not the on-line edition. For each publication, they must report the general information about the trade publication (e.g., the name and address of the publisher, the subscription price, how often it is published, its target audience, the focus of its articles, the focus and type of its advertisements), as well as summarize one article from the publication. Students must use APA format for the bibliographic citation and include a copy of the article they are summarizing. Most of the information presented in the trade publication is very up to date information, so students are able to grasp the current trends and knowledge of the textile and apparel industry. In addition, since we would like to shift the learning responsibility to the students in applying active learning strategy, we provide opportunities to share their summaries of the articles in class. Students select the article they are interested in when they prepare the assignment and then become a teacher when sharing the ideas with the class.

The second assignment gives students an opportunity to explore and prepare themselves for future careers by completing a career investigation project. The final project is a written paper. Students select two careers and one company to investigate. They are required to find information about each career using general career sources and basic company information for their selected organization. In addition, they must conduct an interview with someone in the company who has chosen a career in one of the positions they are researching. 
Students use career publications such as the Encyclopedia of Careers and Vocational Guidance and the Occupational Outlook Handbook, or textile and apparel career specific sources to research the responsibilities and nature of the work (e.g., stress levels, time commitment), background, experience, academic preparation and training needed for the position, career training/advancement, personal qualifications, occupational opportunity, and outlook for the future, including salary expectations. Annual company reports, stock analysis reports and other business sources are used to gather basic information about the company.

Students must find someone within their selected company in one of the two identified jobs to interview. Each student develops a set of interview questions that become part of the final project. Interviews may be face-to-face, over the phone, or via email. The interview allows the students to learn about a specific job in a specific company. For example, students may gather information from the interviewee about his/her job responsibilities, requirements to be hired by the company, promotion opportunities, and evaluation of performance. The interview process was designed to provide students the opportunity to expand their knowledge of careers in a setting (e.g. interview) other than the classroom. It requires them to create their own interview questions and helps them learn professionalism by interacting with professionals in the field. Students thus become responsible for their learning and develop critical thinking skills as they determine how to use and integrate the information gathered into the final paper.

To develop research skills that are essential for problem-solving tasks, we worked in collaboration with an academic librarian to create a course webpage for the career assignment. The webpage contains a list of recommended readings, links to important career websites and instructions on how to assess the validity of web sources they might choose from a general search-engine search. Shortly after the project is assigned, one class period is spent in the library so that the librarian can explain how to conduct electronic searches for print materials, and how to search business and industry databases. Additionally, she discusses the process of evaluating a web site. She uses a link from our web-page to a fictitious website for this activity. By leaving out important information, she demonstrates to students how to help ensure a website is from a reliable source.

We believe that students learn from reviewing others' work and that this is a way to raise the quality of a project. Before the review, time is spent discussing the purpose and process of peer reviews. It is more difficult to do peer evaluations on a written assignment because the work is not as visible as a storyboard, garment design, or poster. However, we have developed a peer review process for this assignment and require each student to conduct a blind review of drafts of two papers. This peer review process also provides the opportunity for the students to revise their paper. As Bean (2001) indicated, students are not usually willing to do so for their class assignments although it is the necessary process for them to think critically about the project. Therefore, we as instructors decided to design this revision process as a form of peer evaluation, and applied it to the class project. Two weeks before the final paper is due, students turn in two copies of their paper. Only a code name appears on the paper. Students use the instructor's rubric to evaluate the papers, making suggestions for improvements and pointing out strengths. Enough in-class time is provided for the students to complete one evaluation so that questions raised by students about the process can be answered. Both reviews are returned the next class period and returned to the author so that revisions can be made, if desired. The peer reviews are not used to calculate the final grade for the project. When the reviews are returned to the author, we discuss the importance of the peer reviews, and the need to critically analyze the comments made by the reviewers. The peer evaluation process provides the students with the opportunity to see others' work often with different levels of quality. In doing so, strong students can be confident with their work and weak students are able to recognize how their quality of work could be improved.

The third assignment is a group retail evaluation project, which requires both a written paper and oral presentation. Because our institution is in a town that does not have a wide variety of retailers to explore, students are assigned to a group based on their hometowns or self-reported information of department stores that are easily accessible to them. Each group of students is assigned a department store - either regularly priced or discount. As a group the students decide on one category of merchandise within the department store to focus on and select a specialty store that sells the same category of merchandise. No two groups can use the same specialty store and efforts are made to ensure most of the product classifications within the department stores are represented by one of the groups. We designed this project to link the course concepts to the students' actual experiences as Norman (1980) indicated that this process can help students apply their existing knowledge to real setting which might be familiar or unfamiliar context.

For this project, students synthesize and apply the information from the class, library research, observations, and interviews. By comparing two types of retailers they see how different retail types position their stores, target customers, advertise, create store images, and merchandise.

By working as part of a group, each student learns about the challenges and rewards of group collaboration and 
research. Students may experience frustration while working with the team, but they also gain confidence and skills in doing quality research and presenting the results. At the same time, they learn about interpersonal communication and problem-solving skills, both of which are required to accomplish a task.

\section{Data Analysis}

Students' responses were gathered using open ended questions at the end of the semesters. The researchers reviewed the students' evaluation and assessment throughout the projects applied during the semester. Each response was categorized into the comments about the projects, the class, and students' professional development.

\section{Students' Responses to the Projects and Class}

All these projects require student inquiry and active involvement in learning, which have been accepted as critical to college teaching and learning. The students' evaluations of the projects were very positive. In written evaluations of the class at the end of the semester, many expressed an appreciation for the class projects and described them as a very useful way to learn and understand the class topics and contents. These responses confirmed that the active learning strategy was helpful to grasp the class materials and contents (Fox-Cardamone \& Rue, 2003; Myers \& Jones, 1993). The students also reported that it provided great opportunities for them to receive an overview not only of their major, but also of future career possibilities. Several students even reported getting part-time jobs from the interviews and expressed the importance of beginning the networking process. It was very important to combine opportunities to learn about the career possibilities with a variety of learning methods in the introductory course, so that students become co-creators of knowledge and not just recipients of it. Applying active learning and students' inquiry promoted a teaching strategy that focus on students and makes them, not teachers, responsible for their learning (Luckie et al., 2004; Scholes, 2002). In addition, our students were able to take their first step into the professional world by initiating contact giving them opportunities to think about their professional and academic goals. At the end of the semester, some of the students expressed confidence in their choice of major and their ability to attain their future goals. In our practices, active learning and student's inquiry is a teaching strategy that positively influences not only students' academic achievement but also their professionalism. Therefore, we believe that it is very important to engage students in inquiry by employing a variety of active learning opportunities early in the curriculum. These activities teach skills that will be required throughout their academic and their professional careers.

\section{Conclusions and Implications}

As there has been much support for the use of active learning in higher education (Bonwell \& Eison, 1991; van Zee, 2000; Wilke, 2003; Wood, 2005; Yoder \& Hochevar, 2005), our teaching strategy that applies the active learning and students' inquiry into introductory merchandising class revealed that both students and instructors value active learning activities. We believe that our examples and practices would be beneficial to other educators wishing to develop a teaching strategy based on student-centered learning. This paper is based on our practices and experiences in our classroom, not on empirical qualitative and/or quantitative research; this is one limitation of the paper that presents an avenue for future research. Empirical research should be done on students' perceptions of active learning projects and students' inquiry. As the university setting becomes more diverse, teachers need to apply a variety of activities in order to ensure active learning; therefore, investigating the relationship of students' diverse characteristics and their response to the class activities and teaching strategies would be meaningful for future research.

We suggest that future research investigate the students' perception of these activities. More research should analyze the benefits and limitations of active learning and institutions should examine ways in which they can support faculty to implement active learning. In addition, there should be longitudinal research to examine how active learning and student inquiry are helpful for students throughout college and in their professional lives.

\section{References}

Bonwell, C. C., \& Eison, J. A. (1991). Active learning: Creating excitement in the classroom. Washington, DC: George Washington University.

Eyler, J. (2000). Focusing student inquiry: The beanbag press conference. College Teaching, 48(2), 61. http://dx.doi.org/10.1080/87567550009595814

Fox-Cardamone, L. \& Rue, S. (2003). Students' responses to active-learning strategies: An examination of small-group and whole-class discussion. Research for Education Reform, 8 (3), 3-15.

Kane, L. (2004). Educators, learners and active learning methodologies. International Journal of Lifelong Education, 23(3), 275-286. http://dx.doi.org/10.1080/0260/37042000229237 
Kumar, S. (2003). An innovative method to enhance interaction during lecture sessions. Advances in Physiology Education, 27(1), 20-25. http://dx.doi.org/10.1152/advan.00043.2001

Luckie, D. B., Maleszewski, J. J., Loznak, S. D., \& Krha, M. (2004). Infusion of collaborative inquiry throughout a biology curriculum increases student learning: A four-year study of "Teams and Streams." The American Physiological Society, 28(4), 199-209. http://dx.doi.org/10.1152/advan.00025.2004

Mattson, K. (2005). Why "Active Learning" can be perilous to the profession. Academe, 91(1), 23-26. [Online] Available:

http://aaup.org/AAUP/CMS_Templates/AcademeTemplates/AcademeArticle.aspx?NRMODE=Published\&NRNOD EGUID $=\{30$ CFB20A-252E-4ECE-A32D-59577988E27B $\} \&$ NRORIGINALURL=\%2FAAUP\%2Fpubsres\%2Facad eme\%2F2005\%2FJF\%2FFeat\%2Fmatt.htm\&NRCACHEHINT=NoModifyGuest

Morgan, A. L. (2003). Toward a global theory of mind: The potential benefits of presenting a range of IR theories through active learning. International Studies Perspectives, 4(4), 351-370. http://dx.doi.org/10.1111/1528-3577.404002

Myers, C., \& Jones, T. (1993). Promoting active learning: Strategies for the college classroom. San Francisco: Jossey-Bass.

Norman, D. A. (1980). What goes on in the mid of the learner. In W. J. McKeachie (ed.), Learning, Cognition and College Teaching. New Direction for teaching and learning, (2). San Francisco: Jossey-Bass.

Scholes, M. (2002). Games worth playing: Effective science teaching through active learning. South African Journal of Science, 98(9/10), 497-499. [Online] Available: http://unllib.unl.edu/LPP/f-smith.pdf (January 10, 2010)

Umbach, P. D., \& Wawrzynski, M. R. (2005). Faculty do matter: The role of college faculty in student learning and engagement. Research in Higher Education, 46(2), 153-183. [Online] Available: http://www.eric.ed.gov/ERICWebPortal/search/detailmini.jsp?_nfpb=true\&_\&ERICExtSearch_SearchValue_0=ED4 91002\&ERICExtSearch_SearchType_0=no\&accno=ED491002

van Zee, E. H. (2000). Analysis of a student-generated inquiry discussion. International Journal of Science Education, 22(2), 115-142. http://dx.doi.org/10.1080/095006900289912

Wilke, R. R. (2003). The effect of active learning on students characteristics in a human physiology course for nonmajors. Advances in Physiology Education, 27(4), 207-223. http://dx.doi.org/10.1152/advan.00003.2002

Wood, B. S. (2005). Lecture-free teaching in seven steps. The American Biology teacher, 67(6), 334-342. http://dx.doi.org/10.1662/0002-7685(2005)067[0334:LTISS]2.0.CO;2

Yoder, J. D., \& Hochevar, C. M. (2005). Encouraging active learning can improve students' performance on examinations. Teaching of Psychology, 32(2), 91-95. http://dx.doi.org/10.1207/s15328023top3202_2 


\title{
On the Internationalization of Higher Education Institutions in China
}

\author{
Jun Liu \\ College of Foreign Languages, North China Electric Power University \\ No 2, Beinong Road, Huilongguan, Changping District, Beijing 102206, China \\ E-mail: liuj59@126.com \\ Zhongxin Dai \\ College of Foreign Languages, North China Electric Power University \\ No 2, Beinong Road, Huilongguan, Changping District, Beijing 102206, China \\ E-mail: zhongxindai@126.com
}

Received: January 10, 2012 Accepted: January 18, 2012 Published: March 1, 2012

doi:10.5539/hes.v2n1p60

URL: http://dx.doi.org/10.5539/hes.v2n1p60

\begin{abstract}
This paper discusses issues concerning the internalization of higher education institutions in China. Internationalization of a university involves the internationalization of the curriculum, the administration and management, collaborative academic research, and exchange of students and staff.
\end{abstract}

Keywords: Internationalization, Higher education, Institution, China

\section{Introduction}

The past three decades has witnessed significant progress in the higher education system in China in response to the burgeoning economy and favorable policies from the government. As the carrier, bearer or vehicle of higher education, institutions (the body of which consists of universities and colleges) have undergone expansion, merging and internationalization. The issue of internationalization of higher education has generated a huge amount of literature, but precisely how a university undergoes internalization, and how teachers and students experience internalization and eventually become internationalized are issues infrequently addressed.

The suffix "-ize" in the word "internationalize" is a word ending which describes a process by which things or people are brought into a new state of the quality of the adjective. Therefore, to "internationalize" a university is to make it become "international". The "internationalization" of a university refers to the process by which the university is made to assume the characteristics or features of being international. A university, as a knowledge-producing entity, consists of administrative organizations, staff members, students, facilities and resources, buildings, etc. It also has its own history, culture, and operating system. It has tripartite mission: teaching, research and service (Maringe \& Foskett, 2010). If we compare the entity of a university to a machine, the machine as a whole would first be internationalized, and then the product (i.e. the students) would assume the international quality. It is easier to talk generally about the internationalization of a university, but when it comes to the detailed concrete step-by-step process, it is quite likely that we become bewildered as to how to approach the issue of internationalization of a university. In this paper, we intend to address three concrete issues: the internationalization of curricula and teaching, of management, and of communication, in the hope of depicting an overall picture of the internationalization process of a university.

\section{Internationalization of Curricula}

The word "curriculum", stemming from the Latin word for race course, refers to a systematic set of courses, including their content, taught by teachers. In a university, the entire university curriculum is composed of a hierarchical system of courses with some being basic or fundamental for some specialties, and some being more specific and practical. The central task of a university is the designing and implementation of its curriculum. The curriculum is regarded as the course in which students experience what they are supposed to experience and grow with the experience. The value of the existence of a university is that it provides a curriculum that satisfies the need of the society or community and the needs of people pursuing post-secondary education and development. In a sense, the internationalization of a university is the internationalization of its curriculum, and hence the internationalization 


\section{of students' experience.}

According to Dewey (1963), the quality of education is based upon the quality of experience. Dewey's ideas hinge on the relationship between education and experience. There are two principles of experience: continuity and interaction, which are the longitude and latitude of experience. Learning is on-going. Every experience changes the individual and potentially opens the doors for more learning. From this point of view, the principle of continuity of experience means that every experience both takes up something from those which have gone before and modifies in some way the quality of those which come after. Experience is a moving force. Its value can be judged only on the ground of what it moves towards and into. Therefore, experiences can be categorized as possibly being educative, mis-educative or simply non-educative. An educative experience is one that contributes positively to the student's growth in the direction where the student is expected to move. A mis-educative experience is one that stops or distorts the student's growth for future experiences. A non-educative experience is one in which a person has not done any reflection and so has obtained nothing for mental growth. "Interaction" expresses the educational function and force. It refers to both the objective and the internal conditions. Any normal experience is an interplay of these two sets of conditions. Taken together, or in their interaction, they form what we call a situation (Dewey, p.42).

Jane Knight (1993, 2003, 2004) defines internationalization as the process of integrating an international, intercultural, or global dimension into the purpose, functions or delivery of post secondary education. We extend this definition into the internationalization of the curriculum. The internationalization of the curriculum of a university is to integrate the international, intercultural or global dimension into the teaching and learning activities of the university. We draw upon Dewey's conception of "continuity" and "interaction" in the discussion of the internationalization of curriculum in a university. If we believe in the conception that the student's experience leads to his growth, it goes without saying that we want our students to have experience with international and intercultural interactions or situations. The next thing we are to consider is what constitutes the daily situation where students gain their experience. Students interact with instructors and administrative staff members, course-books and other resources, experimental equipment and instruments, learning facilities, manners of instruction and administrative management, rules or regulations, and many other numerous things. If they communicate with people with international or intercultural qualities or traits, they themselves may learn how to behave in communication and reflect on the differences between intra-cultural and intercultural communications. If they experience a course offered by a foreigner, then it is quite natural that they experience not only the content of the subject matter of the course, but the instructor's approach to the teaching content, his manner of behavior, his beliefs, his worldview, and his attitudes towards the teaching profession, towards research, towards life, towards society, and towards the students. This perspective on the internationalization of curriculum puts us in a position to view the issue from the following aspects.

\section{(1) Instructors with international and intercultural background}

Internationalization of the curriculum in a university cannot be rendered possible without internationalization of the instructors. Most of the student's experience is composed of interaction with his instructors. The interaction experience with the instructors contributes greatly to the student's academic and intellectual growth. The instructors' knowledge of the subject matter of the courses, their earnest pursuit of scientific truth, hard work and perseverance, attitudes towards life and the world, work or professional ethic, and even their love and interest, all affect their students via interaction with them in and outside class. Instructors with international and intercultural background know very well what their students need in order to make them "internationalized" as the instructors themselves have undergone the experience of internationalization.

There are implicit and explicit approaches to the exercising of influence on students. Implicit influence is through how instructors behave rather than what they tell their students explicitly. For instance, in China, students are supposed to erase the blackboard for their instructors. An instructor with international and intercultural background may erase the board himself immediately after he finishes his instruction no matter whether he will use the board in the next session. If a student offers to clean the board, the instructor would thank the student for doing so. (In traditional teaching situations, teachers never thank their students for erasing the board.) Students present in the class experience what the instructor does or says to the student and notice the difference between his behavior and the behavior of other instructors. Their awareness of the difference will suffice for them to appreciate the manner of the instructor and think about the underlying ideology. If the instructor explicitly informs his students of the underlying ideology of his behavior, then the influence on the students is an explicit one. Another example: an instructor may assign students to accomplish a project in a group with each playing a different part in the project. The students will finish the project and develop the ability to work in a team. The development and growth of the students are unconscious and implicit. But if the instructor explains to the students why they do not have test papers as they formerly do, the students will be consciously aware of the instructor's intention and attempt to develop the 
ability to do team work. Internationalization of class activities and management entails the internationalization of instructors.

(2) Courses analogous to those of comparable universities in the West

The university curriculum contains a set of courses, more exactly a hierarchical set of courses. A university has different colleges, which is further divided in China into departments. Courses or course modules are grouped to meet the requirements of different majors. The grouping of courses or course modules is held responsible for the specifications of the graduates. In this sense we say that the quality of the graduates can be well judged by the courses the university offers to them. If universities in China want to catch up with universities in developed countries, they should first of all design and develop their courses analogous to the courses in those universities. The internationalization of courses involves judgment of the advance and relevance of knowledge, i.e. what knowledge area should be included, the arrangement of the courses, the approaches to the implementation of the courses, etc.

(3) A foreign language as a working language

Language is a tool for communication. If students are expected to communicate with foreigners upon their graduation, it is advisable to use the language of the foreigners in class. English is regarded as an international language, and therefore in most cases English is used in bilingual courses in China. The English language requirement demands instructors with high English proficiency. Those who cannot conduct their instruction in English may use English course-books and give lectures in Chinese; those with high English proficiency may select English materials for their lectures or choose course-books in English and add supplementary materials in English. In order to internationalize students, the content of the subject matter of the courses opened to them should be verbalized in the language in which they will communicate in the future with foreign researchers working in the fields of the subject matter. This is an important part in the internationalization of students. When we speak of the internationalization of students, we do not mean that every part of the students, physical or spiritual, can be converted into something international. We simply indicate that they can use English to share with foreigners their ideas, feelings, beliefs, value judgment, etc. in an across-cultural manner.

Reasonable proficiency in English is a prerequisite for the courses offered in English. Only with this prerequisite can bilingual courses or courses in English be offered, foreign teachers employed, foreign students accepted on a large scale, and cooperative education programs made possible. In this sense, College English (a special term in China to refer to English taught to non-English majors) teaching in China is not just part of the quality-oriented education, but it is held responsible for the important task of the internationalization of the university. The English proficiency of the teachers and students of a university indicates the degree and potential possibility of the internalization of the university. Internationalized prestigious universities can form dialogues with international counterparts in English on all levels. Therefore, it is no surprising to find that English courses for general and specific purposes are placed in an important position in most developing countries all over the world.

\section{Internationalization of University Management}

University management has its own internal and external operating mechanisms. Follow the mechanisms of operation, and a university will prosper and flourish; otherwise, it will stop developing or move in a wrong direction. For many years in the past, universities in China were run on experience, and under the planning system and "red-tape" administration. Since the 1980s, higher education system has significantly changed, but the change of higher education system does not mean the change of ideology, or the raising of the level of scientific management. Time is needed for the change of ideology and improvement of management. It is high time that university administrators investigated the development and management of higher education and the demands of contemporary society and economy on higher education. When they have learned to employ the theories of marketing and value relations, they will be in a position to "sell" their universities in the national and international markets of higher education, and the university will have its place among competitive universities.

China has become a member of the World Trade Organization. "Education", as an industry, has been included in the General Agreement on Trade in Services, and thus China has become part of the world's education market. Higher education in China has been involved in higher education in the world market. In this context, universities in China are facing enormous challenges, but embracing a lot of potential opportunities for development as well. As an independent legal entity, a university should change its ideology, conduct self-management, participate in the competition, and seek its own proper way for development. These are crucial factors that impede the internationalization of universities. As universities in China have just started internationalization, and still have drawbacks of the planning system, international exchanges and dialogues have not been initiated at all levels of universities. The managers or administrators of a university are supposed to make policies to encourage and stimulate internationalization, make significant breakthroughs and initiate launch programs. 
With higher education in China opening up to the world, institutions of higher education have become a promising international market for other institutions of higher education in the world. Meanwhile, the internationalization of higher education in China has become increasingly intensified. The management of a university has to face an open environment both national and international. All universities in China compete in the international market and compete among themselves in the national market. The open and competitive environment requires universities in China to make corresponding policies. Open and competitive management means free competition and flow at all levels of a university. Universities compete with other universities domestic and abroad, and different levels inside a university compete with each other. An open and competitive education market resembles an open and competitive economic market, requiring managers to use the model of economic management in the management of higher education.

Since the 1980s, higher education institutions have become real entities of their own business, and the role of the government is to guide and supervise by way of making policies and legislation. The open environment and the role of self-management require university managers and administrators to update their notion of international and market-oriented education, equip themselves with keen insights and make full use of and take advantage of the resources available. The quality of the administrators and managers of higher education institutions guarantees the quality of their internationalization.

\section{Collaboration with Institutions Abroad}

Frequent exchanges and collaboration with foreign universities feature in the internationalization of higher education institutions. A large proportion of the school routine work is dealing with internationalization affairs. In other words, international businesses have become part of daily routine, and relevant news is no longer shocking news. As internationalization occurs at all levels of the university, exchange and collaboration also occur at all levels. Three areas of exchange and cooperation are identified: academic research, collaborative education and exchange of teachers and students. Exchange and collaboration in the area of academic research are an important aspect of the internationalization of a university. A university expands its cross-border research on the bases of its academic tradition, conditions and advantages. Multinational research can take many forms. It can be short academic conferences or seminars, or collaborative research projects in the research field. Collaborative education also takes many forms, and is sometimes used as an umbrella term covering both academic research and cooperation programs of exchanges of staff and students. This can be illustrated in the list of current cooperative programs of Jiangsu University (Note 1).

1) Wilfrid Laurier University (Canada) “2+2” Photoelectricity Inter-university Exchange Program

2) Jiangsu-Ontario University Student Exchange Program

3) Work \& Travel USA Program

4) Jiangsu University \& Houston University “ $3+1$ ” Student Exchange Program

5) University of California at Berkeley Short-term Academic Visit Program

6) University of California at San Diego Short-term Academic Visit Program

7) Jiangsu University \& Yeungnam University (Korea) Inter-university Student Exchange Program

8) Jiangsu University \& Chienkuo Technology University (Taiwan) Student Exchange Cooperative Program

9) Professional Field Work in Chemnitz (Germany)

10) Jiangsu University \& Leeds University (UK) Food Science and Engineering Undergraduate Cooperative Education Program (international courses pilot class)

11) Jiangsu University \& Arcadia University (USA) Mathematics and Applied Mathematics Undergraduate Cooperative Education Program (international courses pilot class)

We can see from the above list what an average university is currently doing in terms of cooperative educational programs. It should be pointed out that against the large population of the university, the number of staff members and students involved in the current programs is remarkably small.

\section{Conclusion}

The value of internationalization of higher education institutions has been recognized by all universities in China, which can be justified by the vision statement and strategic plans of the universities. However, the recognition of the value of the internationalization is one thing, and the implementation of the strategic plans or the realization of the visions is another. Challenges still remain in the coherence and integration of internationalization within a university with respect to the internationalization of the curriculum and teaching, administration and management, exchange of 
students and staff, and collaborative academic research. Universities in China have accumulated a wealth of innovative ideas. Each university needs to understand its own tradition and culture, and to carefully assess what it has done, what it can do and what will work well. It is hoped that through the experience of the practices it has undergone, through integration of all the current good practices, and through the endeavor that it will make to implement its strategic plan of internationalization, each university will eventually establish its overall supportive policy frameworks to encourage and stimulate internationalization at all levels.

\section{References}

Dewey, J. (1963). Experience and education. New York: Collier Books.

Knight, J (1993). Internationalization: management strategies and issues. International Education Magazine. 9, 6, $21-22$.

Knight, J. (2003). Updated internationalization definition, International Higher Education. 33, 2-3.

Knight, J. (2004). Internationalization remodeled: Definition, approaches, and rationales. Journal of Studies in International Education. 8, 5-31. http://dx.doi.org/10.1177/1028315303260832

Maringe, F., \& Foskett, N. (2010). Introduction: Globalization and universities. In F. Maringe \& N. Foskett. Globalization and internationalization in higher education: theoretical, strategic and management perspectives (pp.

1-16). London/New York: Continuum International Publishing Group.

Notes

Note 1. http://eng.ujs.edu.cn/cooperation/cooperation-program 


\title{
Internationalization of Higher Education and Its Market
}

\section{- Taking International College as an Example}

\author{
Chen Linhan \\ International College, Guangdong University of Foreign Studies, \\ Baiyun District, Guangzhou City, 510420, China \\ E-mail: 199410395@oamail.gdufs.edu.cn
}

Received: January 4, 2012

Accepted: January 12, 2012 Published: March 1, 2012

doi:10.5539/hes.v2n1p65

URL: http://dx.doi.org/10.5539/hes.v2n1p65

\begin{abstract}
This paper is intended for looking into the inevitability of the internationalization of higher education with the prime causes of it resting in the facts that given such large-size Chinese population, the resources allocated to higher education in China remain insufficient to meet the demand for higher education and that universities in the UK, USA, Australia, and Canada enjoy comparatively "sufficient" or surplus resources on one hand and on the other many of them have sustained a cut in the revenue from the government of ten percent in real terms in the past five years and they will face a further ten percent cut by the end of the decade. Also lassoed in the focus in the paper are the subsequent reciprocity arising from the internationalization of higher education and the various forms of collaboration between the International College, Guangdong University of Foreign Studies and its partners overseas.
\end{abstract}

Keywords: Internationalization of higher education, International college, Collaboration, Programs

\section{Introduction}

Over the recent years, China has experienced significant changes in the structure and delivery of its higher education policy as may be observable by its shifting emphasis from an education policy based on the 'elite' to a new one underpinned by 'mass' education. The year 1999 can be regarded as the watershed between the past and current educational policies with the formal expansion of student recruitment going on to meet the growing demand for higher skilled college graduates required by a burgeoning Chinese economy. However the resources allocated to higher education in China have remained insufficient to meet the demand for higher education given China's large-size population and limited higher education resources. Indeed, the Chinese Ministry of Education noted that by 2008 about 124 million Chinese were of college age and according to a report in China Daily, one of the leading English language newspapers in the country, meeting this demand would have required 800 new universities and colleges at a cost of $\$ 68$ billion. The scale of investment and finance, the infrastructure and the human capital required to establish them are prohibitive. Consequently, foreign educational providers have been encouraged to enter this rapidly developing market.

Marijk C. van der Wende (2003, p.193) illustrated the phenomenon by stating "the fact that the growing and diversifying demand for higher education is not always being sufficiently met by national higher education systems creates market opportunities for foreign providers, which are actively explored by providers in mostly Western countries." Thus it can be argued that the trend in internationalization of higher education has increasingly been encouraged and sustained by the economic activities of globalization itself. Indeed the growth in collaboration between Chinese universities and foreign universities has gone hand in hand with the expanding Chinese economy. Wendy W. Y. Chan (2004, p.32) noted that internationalization, to a certain extent, is response to the impacts of globalization and collaboration between educational providers is one of the most effective means to gain visibility, increase the market share and sustain the competitiveness.

There are many modes of collaboration one of which is the collaboration enacted out through International College. This paper is going to illustrate the phenomenon of the collaboration based on international college as the collaborators' market in China by looking into the International College, Guangdong University of Foreign Studies (GDUFS).

The International College, GDUFS, a consolidation of one of the training centers for studying overseas authorized 
by the Chinese Service Centre of Scholarly Exchange under the Ministry of Education, a training department of foreign languages for improving the foreign language proficiency of home scholars and a language proficiency test center, was founded in 2004 with the permission from the Department of Higher Education of the People's Government of Guangdong Province. Ever since its establishment, the International College has been attaching increasingly great importance to training students for studying overseas and collaborating with the partner universities abroad. It aims to cultivate the talent of those who are able to take part in international competition, using their expertise. Students who reach the entry requirements (passing the prerequisite modules and meeting a range of the IELTS requirements) can further their education in the cooperative universities overseas of their choice, receiving a bachelor's degree awarded by the partner universities.

\section{Demand and Supply}

As far as the demand is concerned, two elements, at least, should be taken into consideration. The insufficient resource base of higher education in China has already been mentioned, whilst universities in the UK, USA, Australia, and Canada enjoy comparatively "sufficient" resources. To attract more students from nations outside the European Union to British Universities, the UK government encouraged the universities to recruit more students. As early as Tony Blair's administration, the UK government launched a campaign of recruiting more overseas students. The universities in the USA, Canada and Australia have their own foreign student recruitment targets. As Margaret Kinnell (1987, p.7) pointed out, "universities had sustained a cut in revenue from government of ten percent in real terms in the past five years and they would face a further ten percent cut by the end of the decade. With the prospect of such bleak financial outlook they must therefore look to other sources of revenue."

There has been a great demand for higher education in China. On one hand, only 23 percent of the young people of college age have the chance to receive higher education. They encounter the inevitable effects of a relative resource shortage. To solve the problem in the near future seems to be impossible because of the large-size Chinese population and the strained financial capability of the government. On the other hand, the universities in China vary in many respects in terms of reputation, fame, social recognition, curriculum, ranking, etc. One third of the universities run four-year programs while the rest operate 2- or 3-year programs. The different attributes amongst the universities create a great difference of attraction upon which students base their University choice . When some of the students cannot go to the suitable universities that they define as 'good', they may turn to the universities outside China. But the high tuition fee is the main barrier preventing them from consuming all their university education abroad. For instance, it might cost a student nearly $£ 30,000$ as tuition fees and $£ 20,000$, covering accommodation, transport and other basic expenses, which amounts to 500,000 yuan in RMB's worth to finish the three-year bachelor study in University of Central Lancashire (http://www.uclan/information/international/fees_and_funding/fees.php) in UK, for example. By contrast, choosing to study in the international college, that is, spending two years in China first and finish the last year in a cooperative university overseas, can help them reduce the expenses by $70 \%$. For example, students in the International College, GDUFS only need to spend per year RMB 45,000 yuan for the tuition fee and RMB 13,000 yuan for accommodation, food and travelling expenses. Therefore, the income constraint provides an opportunity for international education providers to run different programs, such as franchised or articulation programmes, develop branch campuses and so on.

Naturally, universities both in China and from abroad invest in various programs to tap the potential interest inherent in a large market. The international activities of many universities in China and of those from abroad have expanded dramatically in the past decades. Altbach \& Knight (2007, p.209) classify the modes of the international activities as follows:

Cross-border supply - This mode may include distance education (e-learning) and franchising courses or degrees. It does not necessarily require the physical movement of the educational consumer or provider.

Consumption abroad - The consumer moves to the country of the provider. This mode includes traditional student mobility.

Commercial presence - The service provider establishes facilities in another country including branch campuses and joint ventures with local institutions.

Presence of natural persons - This mode includes persons such as professors and researchers, who temporarily travel to another country to provide educational services.

International colleges can thus be located in this context, their form usually possessing some of the following characteristics:

Split-site education - two years study at the home university, and one or two years' completion of study at the 
partner university abroad

Localization of human capital - most of the lecturers are supplied by the home university thereby minimizing the cost base

Support from the partner university - the partner universities support the joint programs by sending staff to help teaching and assure and enhance the programs to ensure appropriate quality

Degree awarding - the successful completion of a student's study leads to the degree of the partner university

Thus the existence of international colleges in the education market ensures that many students' expectations in receiving a higher education of their choice are met.

\section{Successful Factors}

Mazzarol (1998, pp.163-175) of Curtin University of Technology, Australia, examined four characteristics of education: the nature of the education service act, the relationship with the customer, the level of customization and judgment in service delivery and the nature of demand relative to supply. He then went on to examine 17 critical success factors for international education marketing based on these four characteristics. The educational and management practice of the International College, GDUFS, may be grouped according to the key factors of Mazzarol's study:

\subsection{Image and Resources}

Mazzarol lists image and resources and coalition and forward integration as the two most important factors for success for an educational institution in international markets. An international college when cooperating with partners offshore selects partners with a different set of attributes in accordance with the requirements of the Chinese market.

When selecting partner universities, various factors including university image, educational resources, academic strengths and locations are taken into consideration by the International College, GDUFS, for example. The International College has established 24 undergraduate top-up programs with institutions in the UK, America, Australia, Canada, France and Korea. Taking the UK programs as an example, GDUFS has selected partners such as Lancaster University, University of Leicester, University of Essex, Coventry University, University of Gloucestershire, University of Central Lancashire and the University of Westminster. As a result, on one hand, students therefore are provided with various choices including very high ranking Universities such as Lancaster University which has always been very popular among the Chinese students in recent years. On the other hand, those students who are academically not very well qualified for entering a good Chinese university and who simply want to receive higher education at a 'modest' price are not too much concerned with the image of the overseas institution. Besides, those overseas universities obtain different educational resources and academic strengths, which can be reflected in the courses available. Various courses, such as Finance, Marketing, Management, etc. are provided for the students to choose.

\subsection{Coalition and Forward Integration}

According to Mazzarol (1988), many researchers have noticed the importance of possessing international strategic alliances or coalitions. Guangdong University of Foreign Studies, as one of the top three Chinese foreign studies universities, is proud of its international education communication and exchanges. It has set up educational links with 125 educational institutions in many countries and regions and the cooperation with the present partners is highly renowned.

The first phase of the educational service is a very important strategy in order to be able to recruit students. There are two decisions that have to be made concurrently, namely, the financial decision and secondly, the 'when' decision. Firstly, many families may not be able to afford the exceedingly high tuition fees if the child has to study offshore for three or four years for the bachelor's degree but they can strive to pay part of the tuition fee. The existence of international colleges can provide a partial solution to this financial problem. Secondly, parents have to decide when to send their children to study offshore and this may entail a decision as to their children's maturity. International colleges offer a period of transition in which their children can learn how to live independently of their families but within familiar confines of their home country.

\subsection{Possession of Offshore Teaching Programs}

Nicouland (1989, pp.55-65) notes that the inseparability of education production and consumption increases the need for international educational service exporters to integrate forward into the overseas marketing channel and to establish "foreign manufacturing facilities". Services such as education involve a high degree of "consumer/producer interaction" thereby creating a strong desire for direct control and presence by the producer 
during the early phases of export development (Vanermerwe and Chadwick, 1989, pp.79-93).

If we take again, Guangdong University of Foreign Studies, as an example, currently the university cooperates with many partners in the UK, the US and Australia, running $2+2,2+1.5$ or $2+1$ programs all dependent upon the specific requirements of the partners and the applicants themselves. Students study at the International College for the first two years, conforming to the theory on the interaction between consumer and producer in the early phase of export development. This form of cooperation has turned out to be successful with partner universities reporting positive comments about the performance of the students. At the University of Queensland, for example, the average performance score of the domestic students was 5.0 in 2006 while the average performance score of the students sent by the International College, GDUFS, was 5.8, at a significantly higher level.

\subsection{Ability to Offer a Broad Range of Courses/Programs}

Mazzarol (1998) further suggests that the ability to offer a broad range of courses and programs is also a potential source of competitive advantage in international marketing.

This is the case with the International College, GDUFS, which can attract a broad range of students with many different needs. It is because the International College is based at GDUFS which is composed of 17 different Faculties and Schools such as the Faculty of English Language and Culture, the School of English for International Business, the School of Economics and International Trade, the School of Journalism, the School of Informatics that the International College can offer a broad range of programs with the full and active support of the faculties. Therefore the resource base of the International College, GDUFS, provides program diversity in courses such as Economics, International Business Management, International Marketing, International Finance, International Journalism, Computing Science, TESL, Media and Cultural Studies, etc.

\subsection{Quality and Expertise of Staff}

Bharadwaj et al. (1993, pp.19-40) highlight the importance of organizational learning and expertise as a source of competitive advantage.

As mentioned earlier, Guangdong University of Foreign Studies is one of the three top foreign studies universities in China, famous for its high level of teaching and high quality of staff. This has been exploited in the practice by the International College ever since its establishment and explains why on average $90 \%$ of the students can be successfully who are sent to our partner universities every year. Our teaching has been highly appreciated throughout South China.

Moreover, for every course (not including language courses) available at the International College, we apply the course accreditation process to it by inviting once two years the experts and professors from the partner universities to teach or oversee the classroom teaching conducted by the home teachers and by having officials from the Chinese Service Centre of Scholarly Exchange under the Ministry of Education come for inspection on a yearly basis. The top priority of the International College is always quality education and professionalism.

Lastly, in order to reflect the characteristics of internationalization, each year, the International College sends one or two teaching staff to those cooperative universities, covering the UK, America, Australia, etc. for short visits or pursuing degrees, which is good for teaching staff to absorb advanced knowledge and keep abreast of the latest developments in education.

\subsection{Strict Administration over the Students}

There are many other factors that contribute to the successful operation of the International College in recent years. A further feature worth mentioning here is the strict administration over the students.

For example, any use of mobile phones is strictly forbidden in class; any form of electronic games is forbidden in the college including student dormitories; attendance is a must with students disqualified from taking the final examination if they are absent for one third of the total class hours of the relevant courses; three failures in examinations in one semester will lead to students repeating the whole year or being expelled; cheating in one examination will also lead to the cheater repeating the whole year or being expelled. GDUFS has taken the view that only under strict administration will the students learn how to work in a conscientious manner.

All the above factors have contributed to the successful operation of the International College, GDUFS. From 2009 to 2011, 1, 816 students have successfully passed prerequisite modules in the International College, met IELTS requirements and continued to study their rest courses abroad.

\section{Conclusion}

With the deepening of economic globalization, the internationalization of China's higher education has developed 
greatly. The establishment of the International College by Guangdong University of Foreign Studies is a very important means by which the university participates in educational globalization. The International College can not only send Chinese students abroad to make use of the relative surplus of educational resources of its partner universities for their higher education but also allows the college itself to send its teaching staffs to be trained abroad or jointly carry out research programs with academic experts in the partner universities and in this manner import the advanced administrative experience and educational resources from its partners. Furthermore, sending students abroad can also reduce the tension inherent in China's economic growth and the shortage of the domestic educational resources provided by the government. Meanwhile, Guangdong University of Foreign Studies also fulfills its social function of ensuring that more high school graduates receive higher education.

Globally, the world competition is chiefly that of competing for talents. The cultivation of human resources is becoming the nucleus of each country's development strategy with the role of education becoming more important than ever in accelerating a country's development. Designing the strategy for educational development in the $21^{\text {st }}$ century has become a hot topic throughout the world. Thus the existence of international colleges is highly significant in order to develop and cultivate Chinese human resources and to improve the moral quality of the Chinese population.

\section{References}

Bharadwaj, S. G., \& Varadarajan, P.R. (1993). Determinants of Success in Service Industries: a PIMS-based Empirical Investigation, Journal of Services Marketing, Vol. 7, No. 4, 19-40.

Haydock. A. (2012, Jan. 3). International Tuition Fees 2012/2013. [Online] Available: http://www.uclan/information/international/fees_and_funding/fees.php

Marijk C. van der Wende. (2003). Globalization and Access to Higher Education, Journal of Studies in International Education, 2003; 7, 193.

Mazzarol, T. Critical. Success Factors for International Education Marketing, International Journal of Educational Management, 1998, 163-175.

Nicouland, B. (1989). Problems and Strategies in the International Marketing of Services, European Journal of Marketing, Vol. 23, No. 6, 55-65.

Philip G. Altbach \& Jane Knight. (2007). The Internationalization of Higher Education: Motivations and Realities, Journal of Studies in International Education, 2007; 11, 209.

Vanermerwe, S., \& Chadwick, M. (1989). The Internationalization of Services, The Services Industries Journal, January, 79-93.

Wendy W. Y. Chan. (2004). International Cooperation in Higher Education: Theory and Practice, Journal of Studies in International Education, 2004; 8, 32. 